\title{
Teaduslik teooria kui teadusfilosoofia kategooria
}

\author{
Rein Vihalemm \\ Filosoofia osakond, Tartu Ülikool
}

Artiklis arendatakse alternatiivset kontseptsiooni niihästi traditsioonilisele füüsikakesksele teadusliku teooria käsitlusele kui ka seisukohale, et füüsikateooriat ei saa teadusfilosoofias mõista teadusliku teooria mudelina, sest erinevates teadustes on teooriad oma loomult erinevad. Ollakse seisukohal, et teaduslik teooria on ikkagi teadusfilosoofia kategooriana teadusliku distsipliini eripärast sõltumatu. Käsitletakse põhiliselt kahte punkti: (1) miks on teadusfilosoofias põhjust kritiseerida traditsioonilist, füüsika põhjal saadud ettekujutust teaduslikust teooriast? (2) miks ei ole põhjendatud seisukoht, et nt keemias on teaduslik teooria (nt klassikaline keemilise struktuuri teooria) oma loomult füüsikateooriast (nt klassikalisest mehhaanikast) erinev? Traditsioonilise füüsikakeskse lähenemisviisi puhul ei ole piisavalt uuritud, miks õieti füüsikateooria on saanud teadusliku teooria etaloniks. Teoreetilise füüsika keskne teadusekontseptsioon on olnud ühekülgselt orienteeritudmatemaatikale ja loogikale. Kui aga lähtuda teooriast kui mudelite populatsioonist, nagu Ronald Giere on seda teinud ka klassikalise mehhaanika - füüsikakeskse teooriakäsituse traditsioonilise näite - korral, siis osutub see teooriakäsitus tõepoolest invariantseks teatavale tunnetustüübile, mida on alust nimetada teaduslikuks ja mis on selgesti omane ka nt keemiale.

Märksõnad: teaduslik teooria, teooria ja eksperiment, teooria matemaatiline komponent, keemilise struktuuri teooria, mudelite populatsioon

Autori aadress: Rein Vihalemm, Filosoofia osakond, Filosoofia ja semiootika instituut, Tartu Ülikool, Ülikooli 18, 5009o Tartu, Eesti. E-post: rein.vihalemm@ut.ee.

Artikkel on kirjutatud Eesti filosoofia aastakonverentsil Tallinnas 16. juunil 2007 ning rahvusvahelisel teadusfilosoofia kongressil Pekingis 14. augustil 2007 (13th International Congress of Logic, Methodology and Philosophy of Science, 9.-15. august 2007, Peking, Hiina; vt ka Vihalemm 2007b) peetud ettekannete põhjal. Artikkel on osaliselt valminud ETF-i uurimistoetuse 7946 raames.

An abstract in English is available at the end of the article. 


\section{Sissejuhatus}

Küsimus 'Mis on teaduslik teooria?' näib olevat kaotanud teadusfilosoofias oma keskse koha. Meenutame aga nt järgmist iseloomulikku märkust 1970. aastaist: "Pole suur liialdus väita, et teadusfilosoofia ei olegi eriti enamat, kui teooriate ja nende rolli analüüs teaduses" (Suppe 1974, 3). Tänaseks on teooria-keskne lähenemine taandunud seoses uue suundumusega teaduse uuringutes, mis taotleb teadust käsitleda selle tegelikus praktikas, niihästi tänapäeval kui ka teadusajaloos. Selle uue suundumusega seostub ka kriitiline hoiak traditsioonilise füüsikakeskse teadusfilosoofia suhtes. Huvitutakse peale füüsika, eriti klassikalise füüsika, mis on olnud traditsioonilise teaduse imago allikaks filosoofias, ka teiste teaduste loomusest ja seatakse peale füüsikateooria loogikalise rekonstrueerimine ka teisi eesmärke. Selles uues situatsioonis, nagu võib lugeda nt üsna värskest ülevaateteosest (Machamer ja Silberstein 2002, 10), on muuhulgas "keemiafilosoofiast saanud üsna "kuum" uurimisvaldkond." Teooriate suhtes arendatakse keemiafilosoofias vaatekohta (nt Schummer 1997a,b, 1998, 2006; Christie ja Christie 2000, 2003), mille kohaselt teaduslikud teooriad on keemias, nagu tegelikult enamuses teadusvaldkondades, oma loomult teistsugused kui füüsikas. Väidetakse, et pole mingit alust arvata, et teooriad peaksid kõikides teadusvaldkondades olema käsitletavad traditsioonilises teadusfilosoofias füüsika põhjal kujunenud vaate kohaselt.

Käesolevas artiklis püüan arendada alternatiivset kontseptsiooni. Ma ei pea õigustatuks arvamust, et nt keemias on teaduslik teooria oma loomult füüsikateooriast erinev. Võtan vaatluse alla klassikalise keemilise struktuuri teooria, mida võib julgesti lugeda kõige tüüpilisemaks keemiateooriaks. Argumenteerin, et see teooria on filosoofiliselt mõistetuna sarnane klassikalise mehhaanikaga, mille alusel väidetavalt on kujunenud lihtsustatud arusaam teooriast. Kaitsen teoreetilist teadusekäsitust, mis kasutab idealiseeritud teaduse kui teoreetilise mudeli mõistet. Teaduse teaduslik-teoreetiline käsitus ei ole võimalik, kui seatakse eesmärgiks võtta arvesse kõigi nende uurimisalade eripära, mida teaduse nime alla paigutatakse. Ent seesugust eesmärki ei olegi mõistlik püstitada. Selle asemel tuleks küsida: miks on füüsika tunnistatud teaduslik-teoreetilise teadmise saamise paradigmaks? Teadusliku teooria mõiste kui teadusfilosoofia kategooria tuleb välja töötada rakendades idealiseerimise ehk teoreetilise modelleerimise protseduuri teooriate konstrueerimise ja nende funktsioneerimise kohta teaduse ajaloolises praktikas. Traditsiooniline teoreetilise füüsika keskne teadusekontseptsioon on olnud ühekülgselt orienteeritud matemaatikale ja loogikale. Palju vähem on olnud Thomas Kuhni algatatud ajaloolist ja paradigmale orienteeritud analüüsi (vt eesti keeles: Kuhn 2003, ka järelsõna: Vihalemm 2003b). Teoreetilise füüsikaga võrreldes on keemilise struktuuri teooria kohasem teaduse 
kui erilist tüüpi praktilise tegevuse analüüsimiseks. Viimast tüüpi analüüsi käigus peame aga ühtlasi küsima: mis õieti on matemaatiliselt formuleeritud füüsikateoorias iseloomulik teaduslikule teooriale üldse? Niisugune analüüs aitab paremini mõista füüsikateooriat kui kõigi teaduslike teooriate teoreetilist mudelit. On ju ilmne, et filosoofiliselt ei saa rahulduda seisukohaga, et matemaatiliselt formuleeritud füüsikateooriaks olemine lihtsalt ise ongi aluseks, miks füüsikateooria on saanud teaduslikkuse kehastuseks üldse.

Käsitlengi siis järgnevalt põhiliselt kahte punkti: (1) miks on teadusfilosoofias põhjust kritiseerida traditsioonilist, füüsika põhjal saadud ettekujutust teaduslikust teooriast? (2) miks ei ole põhjendatud seisukoht, et nt keemias on teaduslik teooria (nt klassikaline keemilise struktuuri teooria) oma loomult füüsikateooriast (nt klassikalisest mehhaanikast) erinev?

\section{Traditsioonilise käsituse kriitika: teooria baseerub mudelitel}

Nagu juba öeldud, traditsioonilise, füüsika põhjal saadud ettekujutuse kohaselt on teaduslik teooria eelkõige matemaatiliselt formuleeritud ja hüpoteetilis-deduktiivselt üles ehitatud. Selle ideaaliks on aksiomatiseeritud süsteem, mis erineb matemaatika aksiomatiseeritud teooriast üksnes selle poolest, et ta omab empiirilist interpretatsiooni, peab olema seostatav eksperimendiga. Teatavasti klassikaline seisukoht teaduslikust teooriast on tuntud loogilise empirismina. Seda klassikalist seisukohta, mida hakati kutsuma omaksvõetud vaateks ("The Received View"), on nüüd nimetatud ka kunagi omaksvõetud vaateks ("The Once Received View (ORV)") (Craver 2002). See järgis Rudolf Carnapi põhimõtet: "Filosoofia tuleb asendada teaduse loogikaga - ...teaduse loogika ei ole midagi muud, kui teaduse keele loogiline süntaks" (Carnap 1937, xiii). Niisiis tegemist oli süntaktilise lähenemisviisiga. Eesmärgiks oli püüelda ideaali poole, mis seisnes selles, et teaduslik teooria tuleb loogiliselt rekonstrueerida, esitada aksiomaatilise süsteemina. See on teada-tuntud seisukoht, millel pole põhjust pikemalt peatuda (ka eesti filosoofiakirjanduses on loogilis-empiristlikku teooriakäsitust ning selle evolutsiooni ja kriitikat iseloomustatud, vt nt Vihalemm 1979, 19-43, 174-241). Võiks üksnes reprodutseerida siin, Ronald Giere'i eeskujul (Giere 1988, 25), kelle vaadetest edaspidi paljuski lähtun, ühe ülevaatliku skeemi loogilise empirismi "ortodokssest" teadusliku teooria käsitlusest (Feigl 1970) (joonis 1), et selle taustal (sh järgmisena reprodutseeritavate skeemidega kõrvutatult) tuleks alternatiivne lähenemisviis selgemini esile. 


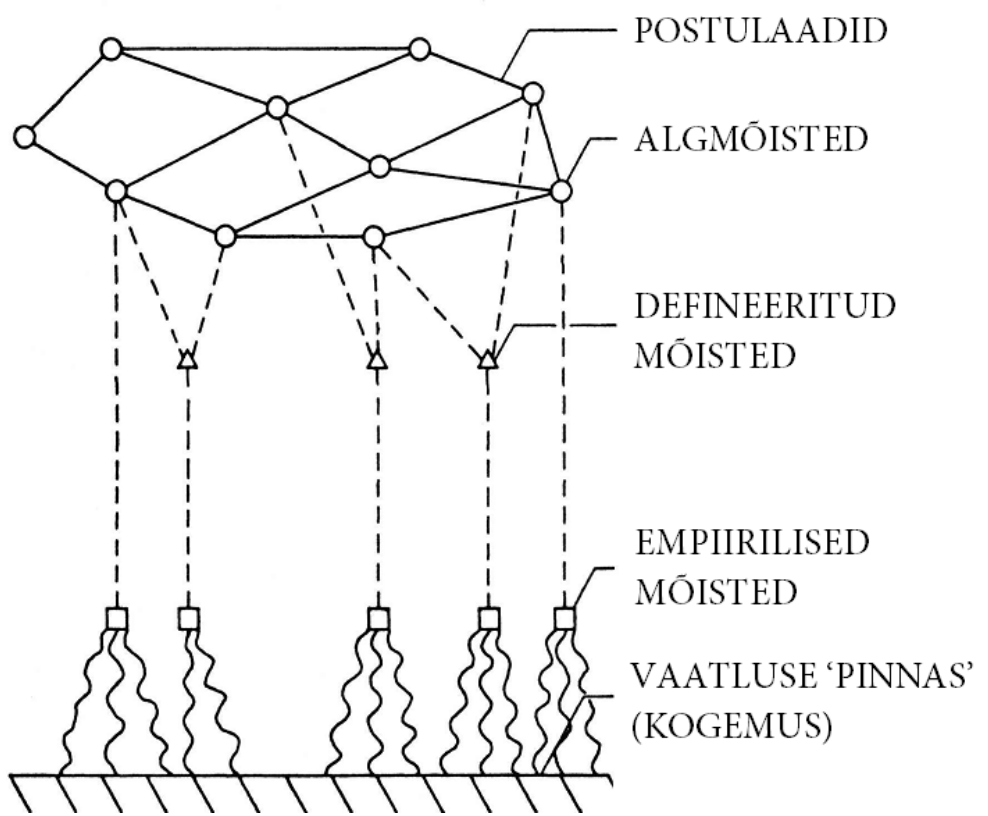

Joonis 1. Loogilis-empiristlik teadusliku teooria käsitlus Feigl'i järgi.

Kõnealust loogilis-empiristlikku, süntaktilise rõhuasetusega lähenemisviisi on veel nimetatud ka väiteliseks (või väitekeskseks) teooriakäsituseks ("the statement-view of theories"), millele on vastandunud "semantiline" lähenemisviis ehk mitte-väitekeskne teooriakäsitus ("the non-statement-view of theories"). Klassikalise süntaktilise teooriakäsituse laiaulatusliku kriitika alguseks sai 1969 a Illinois’i sümpoosium (vt Suppe 1974). Selle sündmuse 30.-aastapäeva puhul ilmus rida tagasivaatavaid analüüse, milledes rõhutati, et "sügav seos mudelite ja teooriate semantilise analüüsi vahel tõotab anda laienenud arusaamise teooriatest, mudelitest ja sellest, kuidas teadus tegelikult töötab" (Suppe 2000, S114) ning et "teooriate ja mudelite analüüs viimasel 30 aastal on andnud suure panuse teaduse praktika mõistmiseks" (da Costa ja French 2000, S126). Semantiline vaade on arenenud 1970. aastatest alates omakorda üsna mitmes suunas: Patrick Suppes hakkas arendama tegelikult ikkagi teatavat loogikalist kontseptsiooni, ent hulgateoreetilise iseloomuga; kujunes välja nn strukturalistlik suund (Joseph Sneed, Wolfgang Stegmüller jt) ning oma semantilist versiooni arendab väga tuntud konstruktiivne empirist Bas van Fraassen, aga ka teda mitterealistina kritiseeriv konstruktiivne realist Ronald Giere; oma versioon on Frederick Suppe'l jt.

Semantiline lähenemine tähendab siin seda, et rõhuasetus ei ole enam matemaatikal kui teaduskeelel, selle aksiomaatilisel ülesehitusel ning süntaksil, vaid sellel, mille kohta käivad, mida rahuldavad need aksioomid. Nii 
saavad teooria mõistmisel keskseks mudelid kui mittelingvistilised entiteedid. Käesolevas artiklis toetun just Ronald Giere'i konstruktiiv-realistlikule mudelitekesksele teooriakontseptsioonile (Giere 1988, 200o).

Giere on spetsiaalselt viidanud ka Thomas Kuhnile, kelle paradigmad kitsas tähenduses kui näidiseksemplarid on samuti mittelingvistilised entiteedid, aga just need on kesksed nii teadusliku teooria kui ka üldse teaduse funktsioneerimise mõistmiseks. Põhirõhk kaldub niimoodi teadlase tegevuse, teadusele spetsiifilise praktika analüüsimisele. Sealjuures siis osutub, et teadusfilosoofias ei saa enam hästi kinni pidada ka üsna mugavaks osutunud teooria nn tõestamise või põhjendamise konteksti ja teooria formeerumise või nn avastamise konteksti rangest eristamisest ning jätta teadusfilosoofia ülesandeks üksnes esimesega tegelemise. Teadusfilosoofia kontekst on teatavasti viimasel ajal oluliselt laienenud ja on lähenetud, nagu juba öeldud, teaduse tegelikule praktikale, oluliseks on saanud sotsiaalsed, ajaloolised, antropoloogilised aspektid ning püütud hakata huvi tundma peaaegu kõige vastu, mida teaduse nime all tehakse või on ajaloos tehtud ning kus nt matemaatikat pole üldse kasutatud, formaliseeritud teooriaid pole loodud või need pole vähemalt kesksed olnud. Olen aga seisukohal, et see kõik ei tohiks takistada ega eemale peletada siiski ka teaduse kohta teatava kitsama, füüsikasarnase teaduse kontseptsiooni arendamisest, teaduse mõistmiseks teoreetilise mudeli väljatöötamisest. Vastupidi — see laiem kontekst just soodustab niisuguse kontseptsiooni väljatöötamisel adekvaatsema tulemuseni jõudmist (vt nt mu varasemaid töid: Vihalemm 1999, 2001, 2003a, 2004, 2005, 2007a).

Minu arvates on Giere'i mudelite-keskne kontseptsioon väga oluline teadusliku teooria kui teadusfilosoofia üldise kategooria mõistmiseks. Giere’i põhiidee on järgmine (vt joonis 2):

Väidete hulga ja reaalse maailma vahel ei ole [...] otsest seost. Seos on vahendatud teoreetiliste mudelite poolt, nagu on kujutatud joonisel [2].

Muidugi, kinnitused sarnasussuhete eksisteerimise kohta mudelite ja reaalste süsteemide vahel nõuavad teoreetilisi hüpoteese, mis on [...] lingvistilised entiteedid. Ent nende puhul on tõe "liiasusteooria" kõik, mida vajatakse [...]. Vastavusteooria tüüpi tõesuhe on abstraktset mudelit iseloomustavate väidete ja selle mudeli enda vahel. Aga see definitsioonile taanduv vastavus ei ole mingi probleem. Raske representatsioonilise töö koormus ei ole mitte tõesuhtel lingvistilise entiteedi ja reaalse objekti vahel, vaid sarnasussuhtel kahe objekti vahel, milledest üks on abstraktne ja teine reaalne. See vaatepunkt toob välja raskused seoses standardvaatega, mis püüab rajada otsest semantilist ühendust mudelit iseloomustavate väidete ja maailma vahele, elimineerides seetõttu mudelite rolli sootuks. (Giere 1988, 82) 


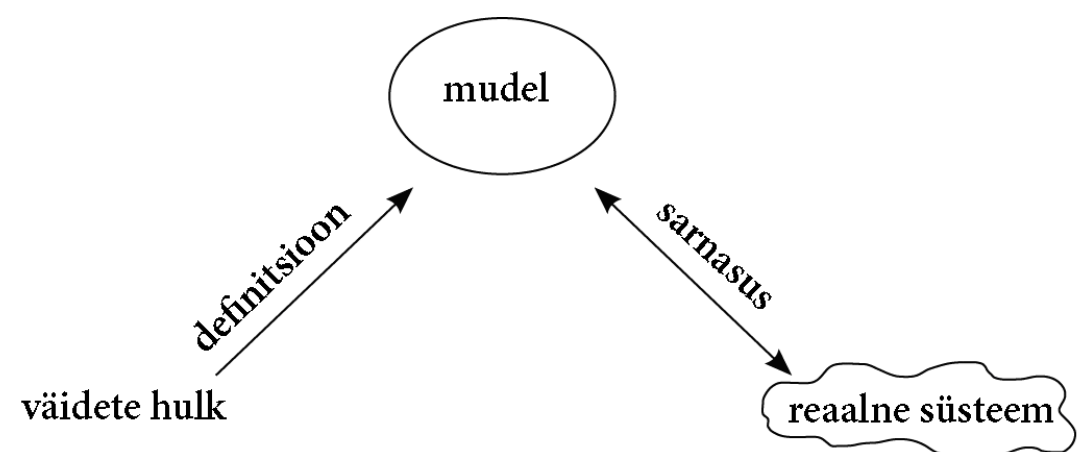

Joonis 2. Seosed väidete hulga, mudelite ja reaalsete süsteemide vahel Giere’i järgi.

Käesoleva artikli kontekstis on oluline tähelepanu juhtida sellele, et Giere’i järgi ei ole teaduslik teooria, nagu ta ütleb, hästidefineeritud mõiste. $\mathrm{Nt}$ ka klassikaline mehhaanika ei ole ega pole kunagi olnud teaduse praktikas lihtsalt aksiomaatiline süsteem, propositsioonide hulk, mille tuumaks on Newtoni 3 seadust ja gravitatsiooniseadus, nagu on küll olnud selle kohta üsna üldine, kaasa arvatud filosoofiline arusaam. Selle arusaama kohaselt on Newtoni teooriat oma kesksete seadustega mõistetud vahetult maailma kohta käivana ning keskseks küsimuseks on peetud teooria ja selle universaalsete seaduste tõesuse küsimust, ükskõik kas siis realismi või üksnes empirismi vaimus (realism on ka enamasti empiristlik olnud). Giere’i järgi aga siis on teoorias kesksed teoreetilised mudelid, idealisatsioonid, mille kohta vahetult käivad ka teoreetilised mõisted ja seadused. Siinkohal on oluline rõhutada, kuigi Giere'i ise seda ei tee, et teoreetiliste mudelite kui idealisatsioonide konstrueerimine eeldab eksperimendi situatsiooni, toimub eksperimentaalselt põhjendatult (vt nt Vihalemm 1979, 110-113, 174-182, 213-215). Selles, kuidas teooria töötab või õigemini - kuidas teooriaga töötatakse, on oluline just töö nende mudelitega, sealjuures mitte üksnes teooria terminite interpreteerimine nendel mudelitel ehk siis mudelite n-ö defineerimine, vaid ka näitamine - see nõuab enamasti nt vastavat aparatuuri -, mis aspektist ning mil määral saab reaalseid süsteeme nende mudelitega identifitseerida. See tähendab teoreetiliste hüpoteeside püstitamist ja testimist. Alles selles suhtes ja siin tuleb mängu ka tõesuse küsimus.

Erinevalt klassikalisest käsitusest ei ole töö mudelitega, ei nende defineerimine ega reaalsete süsteemidega identifitseerimine, teoorias endas kui väidetesüsteemi arendamise raames toimuv tegevus, vaid praktiline, esemeline, eksperimentaalne, ka sotsiaalne tegevus. Oluline on paradigma Kuhni mõttes, millega seostub ka sõnatu teadmine (tacit knowledge). Teaduslik teooria on Giere’i järgi: “(1) mudelite populatsioon, ning (2) mitmesugused hüpoteesid, mis seovad neid mudeleid süsteemidega reaalses maailmas" (Giere 
1988, 85). “[...] [P]ole mingeid vajalikke ja piisavaid tingimusi, mis determineeriksid missugused mudelid või missugused hüpoteesid on teooria osad" (Giere 1988, 86). Need küsimused lahendatakse teadlaskogukonna otsustega. Nii on klassikalise mehhaanika seadused mitte otsesed väited reaalsuse kohta, vaid nad töötavad kui mitmesuguste teoreetiliste mudelite ehk idealiseeritud süsteemide defineerimise vahendid. Klassikalises mehhaanikas on kõigepealt olulised nt niisugused lihtsad konstruktsioonid, nagu lihtne harmooniline ostsillaator, lihtne pendel jt ning nende arendused ja keerukamad konstruktsioonid.

Giere'i iseloomustab nt klassikalist mehhaanikat — seda tüüpilist teooria näidist teadusfilosoofias - skeemiga (Giere 1988, 85) (joonis 3), mis (koos skeemiga joonisel 2) toob ilmekalt esile mudelikeskse teooriakäsitluse erinevuse väitekesksest, mida on eespool iseloomustatud Feigl'i skeemiga (joonis 1).
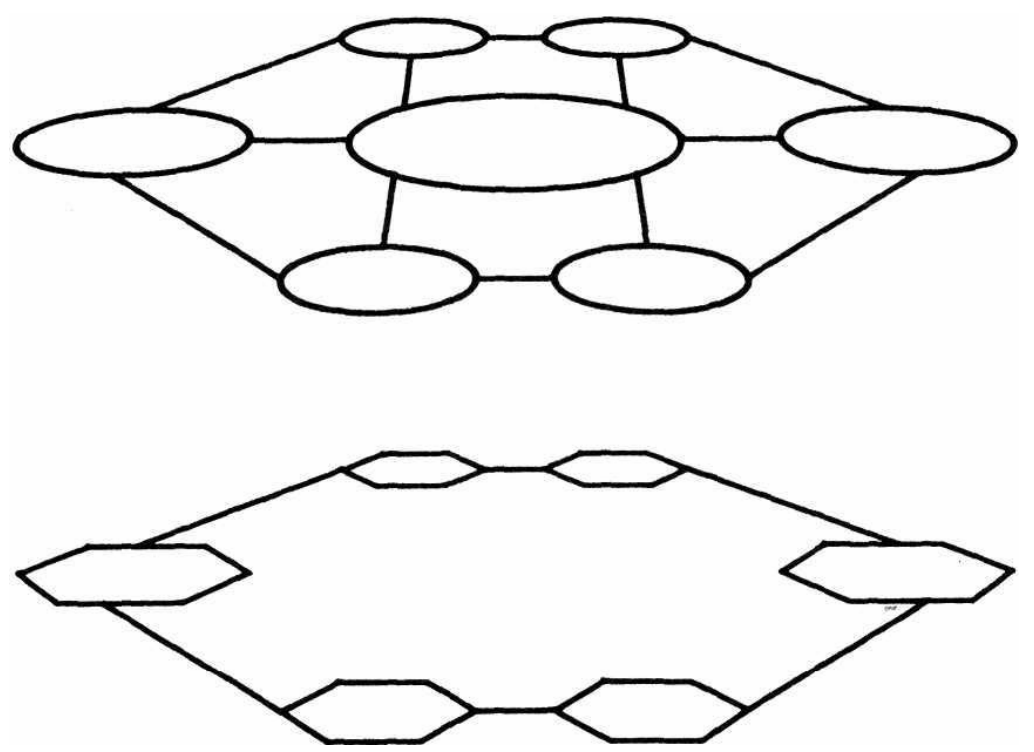

Joonis 3. Teooria kui mudelite populatsioon ja sellega seostatud reaalsed süsteemid Giere’i järgi.

Ellipisid kujutavad sellel skeemil mitte "termineid" või "mõisteid" (mis on kesksel kohal Feigl'i skeemil), vaid mittelingvistilisi entiteete - mudeleid. Seosed mudelite vahel ei ole loogikaseosed, vaid sarnasussuhted. Seostel mudelite ja reaalse maailma vahel ei ole midagi ühist vastavusreeglitega, mis peaksid ühendama termineid omavahel ja maailmaga. Tegemist on jälle mitte loogikaseosega, vaid sarnasussuhetega mudeli ja mõne reaalse süsteemi vahel. Sarnasussuhted nii mudelite vahel kui ka mudelite populatsiooni ja reaalsete süsteemide vahel määratletakse otsustega, mis kujunevad skeemil 
mittekujutatava teadlaskogukonna tegevuses, selles töös mudelitega, mida eespool on kirjeldatud.

\section{Keemilise struktuuri teooria kui teadusliku teooria näidis}

Tuleme nüüd keemia juurde. Võtame hetkeks vaatluse alla tüüpilise keemiateooria - klassikalise keemilise struktuuri teooria. Keemilise struktuuri mõiste on nii klassikalises keemias kui ka oma moodsates versioonides tänapäeval kahtlemata keemia tuum. Näiteks nobelist Roald Hoffmann kirjutab: "Keemilised struktuurid on meie professiooni kaubamärgid, niisama loomulikud keemiale nagu kolvid, katseklaasid ja destillatsioonikolonnid. Kui on näha kedagi usinasti struktuurvalemeid kribimas, siis võib kindel olla, et tegemist on keemikuga" (Hoffmann ja Laszlo 1991, 1).

Niisiis, võiks öelda, et keemia on identifitseeritav keemiliste struktuuride kaudu. Aga küsimus on nüüd selles: miks ja kuidas siis need keemilised struktuurid keemia tuumaks on? Kas ikka juba ülemöödunud sajandi teisel poolel, 186o. aastail loodud klassikaline keemilise struktuuri teooria on vaadeldav filosoofilises mõttes nt klassikalise mehhaanikaga võrdväärse teadusliku teooriana või tuleb tunnistada, et keemias on oma iseäralik arusaam teaduslikust teooriast, mis ei ole ega peagi olema samasugune, nagu arusaam teaduslikust teooriast füüsikas? Viimast on tegelikult üsna sageli väidetud. Või siis on peetud keemilise struktuuri teooriat ja mitte ainult klassikalist, vaid ka selle uusimaid variante $\mathrm{n}$-ö alamõõdulisteks, vähearenenud teooriateks, mis võiksid küll ehk saada ka korralikeks teaduslikeks teooriaiks, aga siis peaks õnnestuma neid füüsikateooriatega põhjendada, ütleme siis tänapäeval kvantfüüsikast tuletada. See keemia füüsikale redutseerimise programm ei ole küll praegu enam populaarne. Keemiafilosoofia püüab pigem keemia eripära rõhutada ja põhjendada. Käesolevas artiklis ei saa muidugi kogu seda problemaatikat käsitleda. On aga oluline rõhutada, et võtan siin vaatluse alla mitte keemia eripära, vaid küsimuse, kas on põhjust rääkida teaduslikust teooriast keemias kui millestki, mis on filosoofilises mõttes füüsikateooriast olemuslikult erinev. Nagu juba sissejuhatuses öeldud, olen seisukohal, et teaduslik teooria kui teadusfilosoofia kategooria peaks oma teadusfilosoofiliselt sisult olema mis tahes teaduse puhul (eeldusel, et on tegemist tõepoolest teadusega) n-ö invariantne mõiste.

Klassikalise keemilise struktuuriteooria mõistmist $n$-ö normaalse teadusliku teooriana raskendab see asjaolu, et tegemist ei ole matemaatiliselt formuleeritud teooriaga selles mõttes, et see ei tugine ühelegi matemaatilisele distsipliinile, ei kasuta matemaatika keelt. Küll on ka siin muidugi tegemist matemaatikaga selles üldises filosoofilises tähenduses, mis on kreeka 
$\tau \grave{\alpha} \mu \alpha \theta \dot{\eta} \mu \alpha \tau \alpha$ nt Heideggeri sõnul - teatav aprioorne teadmine. ${ }^{1}$ Aga ka natuke teadusfilosoofilisemalt öeldes on siingi tegemist matemaatikaga selles mõttes, et on kasutatud idealiseerimisprotseduuri: reaalsetest objektidest, millega teaduslikus praktikas, eksperimendis tegeldakse, on abstraheeritud nendevahelised suhted ning see suhetesüsteem, millesse objektid astuvad on saanud nende käsitlemise aluseks, st ei vaadelda enam reaalseid objekte nendevahelistes suhetes, vaid idealiseeritud objektina suhetesüsteemi, millesse reaalsed objektid astuvad. Idealiseeritud objekt saab oma karakteristikud, oma määratluse selle suhetesüsteemi kaudu (vt Grjaznov 1982, 64). Keskseks idealiseeritud objektiks keemias on puhas aine. Siin tuleb ka ilmsiks, et matemaatika kui teaduse keele funktsioonis on keemias muidugi keemiliste valemite keel - sh siis struktuuriteoorias struktuurvalemite keel. See on üsna range ja eksperimentaalses tegevuses efektiivne keel, semiootiline süsteem, mis

\begin{abstract}
kirjeldab aineid kindlates suhetes üksteisega, st aineid keemilises võrgustikus. [...] iga struktuurvalem vastab ühetähenduslikult kindlale puhtale ainele ja vice versa; ning iga struktuurvalemi modifikatsioon vastab kindlale keemilisele muutusele ja vice versa. Kui on antud nii struktuurvalemite hulk kui ka reeglite hulk lubatud struktuurseteks modifikatsioonideks, siis oleme võimelised genereerima uusi struktuurvalemeid, rakendades neid reegleid olemasolevatele. Niisuguse struktuurse modifikatsiooni tulemus on, definitsiooni järgi, võimaliku aine kirjeldus ja sellena aluseks edasistele struktuursetele modifikatsioonidele vastavalt reeglitele. Kui me selle tõlgime ainete ja keemiliste omaduste keelde, tuleb välja, et me oleme ette näinud uusi aineid, kaasa arvatud nende keemilisi omadusi, ja nende keemilise saamise viisi. Just nii ongi viimase saja aasta jooksul miljoneid uusi aineid ette nähtud ja saadud [...], mis näitab, et keemiliste märkide keel on tegelikult üks ettenägemisvõimelisemaid teooriad teaduses üldse!

(Schummer 1998, 152-153).
\end{abstract}

Lisaks sellele, et keemilise struktuuriteooria formeerumisel ei kasutatud tavalises mõttes matemaatikat, ei saanud isegi rääkida, et tegemist oleks olnud hästidefineeritud väidete süsteemiga. Seetõttu on siiani teatud mõttes ka vaieldavaks küsimuseks nt see, keda tuleks pidada selle teooria autoriks (vt nt Rocke 1981). Põhiliselt ja peaaegu üksnes Nõukogude keemiaajaloolaste, eeskätt Georgij Bõkovi uurimuste kohaselt (Bõkov 1980 jt) on selle ainuautoriks Aleksandr Butlerov, kes esimesena teooria põhiseisukohad 1861. aastal oma ettekandes arstide ja loodusuurijate kongressil Speyeris (Saksamaal) selgelt formuleeris (Butlerow 1861). ${ }^{2}$ Tekib õigustatud küsimus: miks ei ole

\footnotetext{
1 “T $\grave{\alpha} \mu \alpha \theta \dot{\eta} \mu \alpha \tau \alpha$ tähendab kreeklastele seda, mida inimene oleva vaatlemisel ja asjade kohtlemisel enne teab [...]" (Heidegger 1994, 78).

${ }^{2}$ Butlerov kirjutas: "Tõsi, me ei tunne seda seost, mis on liitosakeses teda moodustavate
} 
siis Butlerov läinud keemia ajalukku kui klassikalise keemia keskse teooria vaieldamatu autor? Pole nt mingit alust arvata, et tegemist on pahatahtliku mahavaikimisega vms. Samuti pole erilist põhjust arvata, et nt Bõkov oli lihtsalt suur Nõukogude patrioot, kes Butlerovi upitas, nagu seda paraku omal ajal ka tõesti tehti. Bõkov oli ikka kahtlemata keemia ajaloo tõsine uurija.

Selles küsimuses tuleb muuhulgas (küsimus on üsna keeruline, mida ei saa siin praegu analüüsida; on juba viidatud nt tööle: Rocke 1981) kenasti ilmsiks eespool rõhutatu, et teadusliku teooria mõistmine osutub puudulikuks, kui piirduda üksnes või eelkõige selle käsitlemisega matemaatiliselt formuleeritud väidete süsteemina või üldse väidete süsteemina (st jääda statement-view juurde). Kui aga lähtuda teooriast kui mudelite populatsioonist, siis saab nii mõndagi selgemaks. Ühendite keemilised struktuurid kui keemikute poolt konstrueeritud abstraktsed entiteedid ongi antud juhul need mudelid, millest Giere räägib ja rõhutab, et ei nende n-ö defineerimine ega reaalsete süsteemide (antud juhul - ainete) nendega identifitseerimine ei ole teoorias kui väidetesüsteemi arendamise raames toimuv tegevus, vaid teadlaste praktiline, eksperimentaalne ja sotsiaalne tegevus. Küllap on ka Butlerovi puhul pigem tegu sellega, et kuigi ta sõnastas oma Speyeri ettekandes üsna kompaktselt tolleks ajaks kujunenud põhimõtted keemilisest struktuurist, ei viinud see uue paradigma kujunemiseni keemias. Butlerovi sõnastatud teooria abil ei saanud kuidagi paremini kui varem, mil niikuinii juba kasutati keemikute praktikas kujunenud ainete keemilise struktuuri põhimõtteid, konkreetse struktuuriga ühendit sünteesida või identifitseerida. Selleks vajati ikkagi vastava sünteesimeetodi väljatöötamist, ühendi sünteesimist ja selle omaduste eksperimentaalset uurimist. Verbaalsel formuleeringul on keemias konkreetne sisu ikka ainult siis, kui sellel on selge vaste eksperimendis. Keemias on see selgem, kui nt tänapäeva teoreetilises füüsikas, kus matemaatikal on suhteline iseseisvus sageli nii suur, et piir füüsika ja matemaatika vahel kipub ähmastuma. Aga minu arvates käib põhimõte,

aatomite vastastikuse toime ja nende mehhaanilise paiknemise vahel, - ei tea, näiteks, seda, kas aatomid, mis vahetult üksteisele mõjuvad, kinnituvad otseselt üksteisega, aga sellegipoolest, isegi siis, kui jätame mõiste füüsikalistest aatomitest täiesti kõrvale, ei saa eitada, et liitkeha keemilised omadused on tingitud peamiselt teda moodustavate elementide keemilistest suhetest. Lähtudes mõttest, et iga keemiline aatom, kuuludes keha koosseisu, võtab osa selle moodustumisest ja mõjub siin teatud hulga talle kuuluva keemilise jõuga (sugulusega), ma nimetan keemiliseks ehituseks selle jõu mõju jaotust, mille tõttu keemilised aatomid vahetult või mittevahetult üksteisele mõjudes, ühinevad keemiliseks osakeseks.

Seda tuntud reeglit, mis ütleb, et liitosakese loomus määratletakse elementaarsete koostisosade loomuse, arvu ja paigutusega, võiks minu arvates praegu muuta järgmiselt: liitosakese keemiline loomus määratletakse elementaarsete koostisosade loomuse, nende arvu ja keemilise ehitusega" (Butlerov 1953, 70). 
et "teooriat peetakse tööriistaks keemiliste eksperimentide jaoks, mitte vastupidi" (Schummer 2004, 406), mitte ainult keemia kohta, vaid teooria ja eksperimendi vahekorra kohta teaduses üldse. Teaduslik teooria on ainult siis midagi väärt, omandab teadusliku teooria kvaliteedi, kui ta on eksperimentaalselt põhjendatud, kui teooriale tuginedes saab reaalses maailmas nähtusi ette näha, tekitada ja kontrollida.

19. sajandi orgaanilises keemias sai märksa suurema tähelepanu osaliseks küllalt laia ja vajalike ühendite klassi sünteesimeetodite väljatöötamine kui Butlerovi üsna üldiselt sõnastatud, ent konkreetse ühendi saamiseks siiski vahetult mitterakendatav teooria. Seetõttu pole üllatav seegi, et Butlerov sai ülemaailmselt tuntuks mitte niivõrd uue teooria põhimõtete esimesena kompaktselt formuleerijana, kui mitme sünteesimeetodi ja vastava ühenditeklassi avastaja ja uurijana. Keemilise struktuuri põhimõteteni jõudsid keemikud pikapeale justkui iseenesest, oma eksperimentaalse tegevuse käigus, ilma Butlerovi või kellegi teise üldisi formuleeringuid otseselt aluseks võtmata.

\section{Kokkuvõtteks}

Kuigi hetkel ei ole teadusliku teooria analüüs enam teadusfilosoofias kesksel kohal, ei ole alust arvata, et teaduslikku teooriat ei saa mõista teadusfilosoofia olulise kategooriana. Traditsiooniline füüsikakeskne lähenemisviis, mis oli teooriale orienteeritud, on küll kriitika alla sattunud, ent ei ole piisavalt uuritud, miks õieti füüsikateooria on saanud teadusliku teooria etaloniks. Traditsiooniline teoreetilise füüsika keskne teadusekontseptsioon on olnud ühekülgselt orienteeritud matemaatikale ja loogikale. Teaduse filosoofiline mõistmine eeldab lähtumist teadlase tegevuse, teadusele spetsiifilise praktika analüüsimisest. Teadusliku teooria mõistmine osutub kitsaks ja filosoofiliselt puudulikuks, kui piirduda üksnes või eelkõige selle käsitlemisega matemaatiliselt formuleeritud väidete süsteemina või üldse väidete süsteemina (st jääda statement-view juurde). Kui aga lähtuda teooriast kui mudelite populatsioonist, nagu Ronald Giere on seda teinud ka klassikalise mehhaanika - füüsikakeskse teooriakäsituse traditsioonilise näite - korral, siis osutub see teooriakäsitus tõepoolest invariantseks teatavale tunnetustüübile, mida on alust nimetada teaduslikuks, mis aga ei piirdu enam üksnes füüsikaga, vaid on selgesti omane ka näiteks klassikalise keemia kesksele teooriale keemilise struktuuri teooriale. Tulebki rõhutada, et teaduslikule teooriale on iseloomulik, et selle keskmeks on mudelid kui eksperimentaalselt põhjendatud idealisatsioonid, millele tuginedes saab reaalses maailmas nähtusi seletada, ette näha, tekitada ja kontrollida. Teooria tavalises mõttes matemaatiline (mingist olemasolevast matemaatilisest distsipliinist lähtuv) formuleeritus ei pruugi seejuures tingimata vajalik olla. Teadusliku teooria matemaatilise 
komponendi filosoofiline sisu seisneb selles, et see on teatav keel ja meetod, mis võimaldab idealisatsioonidega opereerida. Keemias näiteks on selleks puhaste ainetega opereerimist võimaldav keemiliste valemite keel, sh struktuuriteoorias struktuurvalemite keel.

Käesoleva artikli üldisemaks järelduseks on, et kuigi ei ole muidugi alust samastada teadust üldse füüsikaga ja teaduslikku teooriat füüsikateooriaga, pole ka mõistlik arvata, et füüsikas ja füüsikateoorias, mille teaduslikkuses keegi ei kahtle, pole midagi niisugust, mis on iseloomulik teaduseks nimetatavale tunnetustüübile üldse ja võimaldab seda teistest tunnetustüüpidest eristada. Teaduse kui erilise tunnetustüübi ja teadusliku teooria kui teadusfilosoofia kategooria iseloomustamiseks tuleb aga siis nii füüsikat kui ka teisi teadusi analüüsida neile kõigile iseloomuliku invariantse praktilise tegevuse aspektist.

\section{Kirjandus}

Bõkov, G. V. (1980). Istorija klassitšeskoi teorii himitšeskogo stroenija, Izd-vo AN SSSR, Moskva.

Butlerow, A. (1861). Einiges über die chemische Struktur der Körper, Zeitschrift für Chemie 4: 549-560.

Butlerov, A. M. (1953). O himitšeskom stroenii veštšestv. Sotšinenija t. 1, Izdvo AN SSSR, Moskva.

Carnap, R. (1937). The Logical Syntax of Language, Routledge and Kegan Paul, London.

Christie, M. ja Christie, J. (2000). "Laws" and "theories" in chemistry do not obey the rules. N. Bushan ja S. Rosenfeld (toim), Of Minds and Molecules: New Philosophical Perspectives on Chemistry, Oxford University Press, New York, lk 34-50.

Christie, J. R. ja Christie, M. (2003). Chemical laws and theories: A response to Vihalemm, Foundations of Chemistry 5: 165-177.

Craver, C. F. (2002). Structures of scientific theories. P. Machamer ja M. Silberstein (toim), The Blackwell Guide to the Philosophy of Science, Blackwell Publishers Ltd, Malden (Mass.), Oxford, lk 55-79.

da Costa, N. ja French, S. (2000). Models, theories, and structures: Thirty years on, Philosophy of Science 67 (Supplement): 116-127.

Feigl, H. (1970). The "ortodox" view of theories: Remarks in defense as well as critique, Minnesota Studies in the Philosophy of Science 4: 3-16. 
Giere, R. N. (1988). Explaining Science: A Cognitive Approach, The University of Chicago Press, Chicago.

Giere, R. N. (2000). Theories. W. H. Newton-Smith (toim), A Companion to the Philosophy of Science, Blackwell Publishers Ltd, Malden (Mass.), Oxford, lk 515-524.

Grjaznov, B. S. (1982). Logika, ratsionalnost, tvortšestvo, Nauka, Moskva.

Heidegger, M. (1994). Die zeit des weltbildes, Holzwege, 7. Aufl., Vittorio Klostermann, Frankfurt am Main, lk 75-93.

Hoffmann, R. ja Laszlo, P. (1991). Representation in chemistry, Angewandte Chemie. International Edition in English 30: 1-16.

Kuhn, T. S. (2003). Teadusrevolutsioonide struktuur, Ilmamaa, Tartu. Tlk. Ruth Lias.

Machamer, P. ja Silberstein, M. (toim) (2002). The Blackwell Guide to the Philosophy of Science, Blackwell Publishers Ltd, Malden (Mass.), Oxford.

Rocke, A. J. (1981). Kekulé, Butlerov, and the historiography of the theory of chemical structure, The British Journal for the History of Science 14: 27-57.

Schummer, J. (1997a). Challenging standard distinctions between science and technology: The case of preparative chemistry, Hyle 3: 81-94.

Schummer, J. (1997b). Towards a philosophy of chemistry, Journal for General Philosophy of Science 28: 307-336.

Schummer, J. (1998). The chemical core of chemistry I: A conceptual approach, Hyle 4: 129-162.

Schummer, J. (2004). Why do chemists perform experiments?. D. Sobczyǹska, P. Zeidler ja E. Zielonacka-Lis (toim), Chemistry in the Philosophical Melting Pot, Vol. 5 of Dia-Logos: Studies in Philosophy and Social Sciences, Peter Lang Europäischer Verlag der Wissenschaften, Frankfurt am Main, lk 395-410.

Schummer, J. (2006). The philosophy of chemistry: From infancy toward maturity. D. Baird, E. Scerri ja L. MacIntyre (toim), Philosophy of Chemistry: Synthesis of a New Discipline, Vol. 242 of Boston Studies in the Philosophy of Science, Springer, Dordrecht, 1k 19-39.

Suppe, F. (2000). Understanding scientific theories: An assessment of developments, 1969-1998, Philosophy of Science 67 (Supplement): 102-115.

Suppe, F. (toim) (1974). The Structure of Scientific Theories, University of Illinois Press, Urbana.

Vihalemm, R. (1999). Can chemistry be handled as its own type of science?, N. Psarros ja K. Gavroglu (toim), Ars Mutandi: Issues in Philosophy and 
History of Chemistry, Leipziger Universitätsverlag, Leipzig, lk 83-88.

Vihalemm, R. (2001). Chemistry as an interesting subject for the philosophy of science. R. Vihalemm (toim), Estonian Studies in the History and Philosophy of Science, Vol. 219 of Boston Studies in the Philosophy of Science, Kluwer, Dordrecht, lk 185-200.

Vihalemm, R. (2003a). Are laws of nature and scientific theories peculiar in chemistry?, Foundations of Chemistry 5: 7-22.

Vihalemm, R. (2003b). Järesõna. "Teadusrevolutsioonide struktuur" nelikümmend aastat hiljem. T. S. Kuhn, Teadusrevolutsioonide struktuur, Ilmamaa, Tartu, lk 287-304. Tlk. Ruth Lias.

Vihalemm, R. (2004). The problem of the unity of science and chemistry. D. Sobczyńska, P. Zeidler ja E. Zielonacka-Lis (toim), Chemistry in the Philosophical Melting Pot, Vol. 5 of Dia-Logos: Studies in Philosophy and Social Sciences, Peter Lang Europäischer Verlag der Wissenschaften, Frankfurt am Main, lk 39-58.

Vihalemm, R. (2005). Chemistry and a theoretical model of science: On the occasion of a recent debate with the Christies, Foundations of Chemistry 7: 171-182.

Vihalemm, R. (2007a). Philosophy of chemistry and the image of science, Foundations of Science 12: 223-234.

Vihalemm, R. (2007b). Scientific theory as a category of philosophy of science: A criticism of the view that scientific theories are discipline dependent, Volume of Abstracts. 13th International Congress of Logic, Methodology and Philosophy of Science, IUHPS/DLMPS, Beijing, lk 281-283.

Vihalemm, R. (toim) (1979). Teaduse metodoloogia, Eesti Raamat, Tallinn. 


\section{Scientific theory as a category of philosophy of science}

In this paper an alternative conception is proposed both to (1) the traditional physicsbased conception of scientific theory, and (2) the view that a physical theory cannot be regarded as the model for scientific theory in philosophy of science in general because scientific theories are discipline-dependent. It is argued that scientific theory as a category of philosophy of science is independent of a particular scientific discipline. The main focus of the paper is on two questions: (1) Why is the traditional physics-based conception of scientific theory subject to criticism in philosophy of science? (2) Why is it unjustified to consider a scientific theory in chemistry (e.g., the classical chemical structure theory, which is probably the most characteristic theory of chemistry) to be different in character from a physical theory (e.g., classical mechanics, which is a prototypical example of a theory in the philosophy of science)? In case of the traditional physics-based approach not enough research has been done as to why theories of physics have become the etalon of scientific theory. The accepted view of science, centered on theoretical physics, has been one-sidedly oriented towards mathematics and logic. But when proceeding from a conception of a scientific theory as a population of models, as Ronald Giere has done for the case of classical mechanics - the traditional example of a physical theory-, this conception of a theory really does prove the invariance of a certain type of cognition that can justifiably be called scientific and that is clearly characteristic of, e.g., chemistry as well.

Keywords: scientific theory, theory and experiment, mathematical component of theory, theory of chemical structure, population of models 